FACTA UNIVERSITATIS

Series: Physical Education and Sport, Vol. 16, No 2, 2018, pp. 375 - 386

https://doi.org/10.22190/FUPES180720034M

Research article

\title{
PHYSICAL EDUCATION TEACHERS AS REFLECTIVE PRACTITIONERS AND ACTION RESEARCHERS IN THEIR WORK
}

\author{
UDC 796.08:727.1:371.213
}

\begin{abstract}
Jelena Maksimović, Jelena Osmanović
Faculty of Philosophy, Department of Pedagogy, University of Niš, Niš, Serbia
\end{abstract}

\begin{abstract}
Physical education classes are peculiar in their character in comparison to classes of other school subjects since they are not taught in a classroom. However, it certainly does not mean that physical education teachers should not reflect on their practical work or analyse it. This process of reflective thinking represents a particular challenge and responsibility for physical education teachers. Therefore, the goal of this research is to determine the way in which they approach this issue, i.e. whether physical education teachers are reflective practitioners and action researchers. The paper used a descriptive method and scaling technique, as well as a Likert type scale (FVAI) scales, designed for the purpose of this research, which examined the teachers' attitudes about physical education in the context of reflexive practice and action research. The survey was conducted on a sample of 405 respondents in relation to independent variables of the type of school (primary and secondary) and years of service (0-10; 11-20; over 20 years of work experience). This research has shown that teachers are partially informed about action research and its application, whereas they highly value all the aspects of reflective teaching. This research contributes to the affirmation of action research since reflection and action are linked in physical education teaching by means of a continuous, unbroken line which further encourages teachers to reflect on their own practice. Teachers who are reflective practitioners are simultaneously action researchers. This research has proven the existence of a statistically significant connection between the reflectivity components of physical education teachers and the stage of education (school) in which they teach and years of teaching experience, $p<0.05$.
\end{abstract}

Key words: action research, reflective practice, physical education, physical education teaching

Received July 20, 2018 / Accepted September 17, 2018

Corresponding author: Jelena Maksimovic

University of Niš, Faculty of Philosophy Ćirila i Metodija 2, 18000 Niš, Serbia

Phone: +381 18 514312•E-mail: jelena.maksimovic@ filfak.ni.ac.rs 


\section{INTRODUCTION}

The teaching profession involves a multitude of complex tasks. Teachers are expected to be experts both in the subject they teach and in the field of teaching in general. In order to accomplish this, they have to continually improve their own knowledge and reflect on their own practice (Momčilović \& Momčilović, 2016). The moment teachers start reflecting on their own teaching practice, they become reflective practitioners.

Reflection presupposes serious thought and consideration of one's own actions and ideas (Akbari et al., 2008), i.e. a reassessment of everything previously accomplished and planned with the purpose of improving one's practice through the analysis of all its advantages and disadvantages (Rodgers, 2002). In the context of teaching, the term reflective practice is used in its original meaning of the word - reflection originally means sending back light by a body or surface. Thus, the term reflective teacher involves a practice in which teachers have to "look themselves in the mirror" and ponder on the reflection of their teaching practice (Budjevac et al., 2013). Challenges of teaching motivate teachers to think seriously about the ways in which to improve their teaching methods. Reflection on one's own actions is the basis of reflective practice (Sanopao, 2016), and each individual teacher is required to both become a reflective practitioner and value their own practice (Fatemipour, 2013). It is important that the teacher pose these two questions to themselves during this process: "What have I done up to now?" and "What can I do to improve it and make it better?" (Kayapinar, 2016).

Teachers who reassess their own actions only when they encounter a problem or who analyse their behaviour only when they believe it could have been more effective are not reflective practitioners (Radišić et al., 2015). A reflective practitioner is a teacher inclined to continuous self-analysis and self-reflection, prepared to apply different and novel methods of teaching, identify good teaching practice, share experiences with colleagues, alter a previously determined plan to suit the pupils' needs, analyse the principles on which their action is based and which they have previously included into their own practice without questioning them. Reflection represents a complete and systematic approach to teaching so that it is not the steps or procedures that should be considered, but the ways of reassessing and reflecting on one's own practice. These may include the following: consideration of one's own work through answering questions about various aspects of teaching, register records, "giving advice", conducting action research, analysis of recorded classes, referring to scientific and scholarly materials related to learning and teaching, recall and analysis of one's own school experiences, debates with pupils and sharing experiences with colleagues (Budjevac et al., 2013).

The best way to implement reflective practice into the process of education is to conduct action research. Action research combines and unites reflective teaching, classroom practice research and quality improvement of teaching, i.e. it represents a cyclic process of learning, developing, acting and reflecting as regards a particular experience (Apasia et al., 2017). Action research is systematic research conducted by teachers with the purpose of collecting information about the way their school works, the quality of their own teaching and their pupils' success in learning (Mills, 2003, p. 5). The schools which favour educational changes encourage their teachers to be active research participants, not only the users of the obtained results. One of the basic characteristics of action research is that problems are identified and resolved by teachers themselves, who do so relying on their own needs, not on the needs of individuals outside their school or other institutions. Also, the central part of the action research is action itself, so it is possible to alter and adapt preplanned activities to new conditions, which 
means that the whole process of research is a flexible and creative response to the needs of the participants in the research. The goals of collecting information in action research is a review of the state of affairs, reflective practice development, creating positive changes at school, as well as enhancing learning results and quality of living of all the research participants (Mills, 2003). Action researchs represent the need to improve all segments of work at school (Budjevac et al., 2013), to enhance the quality of teaching and learning, as well as the teaching and learning conditions. Action research offers support to teachers (groups of teachers) when they are confronted with practical problems and challenges and when they have to introduce innovative methods relying on reflection (Altrichter et al., 2005). In regard to the aforementioned statement, Norton (2009) emphasises that if permanent changes are to be created, the cycle of action research must be based on reflection, i.e. on the reassessment of one's own practice, which, since it includes the transformation of the existing suppositions, should be done by adopting new frameworks. Action research is characterised by a continuous endeavour to both connect and confront action and reflection, to review and reassess conscious and unconscious behaviour with a view of improving action, and to act reflectively in order to advance knowledge. Therefore, both reflection and action are developed: reflection opens up new possibilities for action to be taken, which are then verified and confirmed through the action taken (Altrichter et al., 2005). The regular alternation of action and reflection is the procedure in which the teacher first takes action during teaching and then reflects on their work, which is the basis of their future planning and improving their teaching practice (Boateng \& Boadi, 2015), and which is the basic goal of action research.

The nineteenth century teaching of physical education was based on gymnastics and military discipline. Nowadays, physical education teaching is focused on the programmes of education related to overall anthropological contexts of physical (motor) activities and skills (Rodić, 2010). Physical education is an inseparable segment of general education whose purpose is the development of a versatile and harmonious (Batez et al., 2013), i.e. integral personality of a pupil (Rodić, 2010). Physical education has a positive impact on pupils' health and learning abilities (Peppa et al., 2011). All this proves that physical education plays an important role in the education system of the young (Batez et al., 2013). A great number of scholars have discussed the reflective practice and action research of "coaches" and teachers (Ahlberg et al., 2008; Evans \& Light, 2007; Gilbert \& Trudel, 2001; Hall \& Gray, 2016; Isidori, 2008; Knowles et al., 2001; Knowles et al., 2005; Knowles et al., 2006; Kuklick et al., 2015; Mallett, 2004; McGonagill, 2002; Olis \& Sproule, 2007; Pill, 2014), and their application in the field of sports psychology (Anderson et al., 2004; Cropley et al., 2010; Cropley et al., 2012); however, the practice of conducting action research in the field of physical education has been introduced comparatively recently (Robinson, 2013).

Reflective practice is a unique construct which encompasses study and research in which the teacher really acts (Huntley et al., 2014). Moreover, reflective practice is the key factor for improving teaching and for gaining better teaching experience (Anderson et al., 2004; Knowles et al., 2005). Reflective practice requires that physical education teachers reassess their own values and actions since it enables them to comprehend goals and values, as well as to find enough support for their own practice. This is the reason why it is very important that physical education teachers be well trained for a valuable self-evaluation, i.e. reflection on their own training practice and on their acts (Grk, 2010).

Reflection is focused on the following questions: What values do I promote through physical activity and sports? How can I make my behaviour useful to others? How do I 
organise my work in order to best promote the values of my profession? Are there any moments in which I do not promote these values? etc. (Isidori, 2008). These questions are answered by conducting action research (Ahlberg et al., 2008). According to Pill (2014), action research is a useful tool for the enhancement of physical education teaching since it contributes to the promotion of critical thinking and reflective practices whose aim should be the resolution of various problems arising in particular situations.

A former teacher of physical education, Robinson (2013) conducted an action research on how female pupils were satisfied with physical education classes into which he included the teachers of physical education, as well, attempting to stimulate them to develop their own action strategies by themselves. The willingness of these teachers to participate in this action research was some kind of professional hazard: the teachers accepted and confirmed the fact that their teaching was not satisfactory. The author concluded that it was the only way that these teachers, by accepting their own drawbacks, be included into the action research with the purpose of "filling the holes" in their own knowledge, skills and competences. In addition, by being participants in the research in which they reassessed their own practice, purposefully planned how to enhance it by taking into account the results of their actions/interventions and by repeating the cycle of the action research, these teachers became teachers-researchers.

\section{METHODS}

\section{Goals and issues}

Primary and secondary school physical education teachers regularly evaluate and assess their pupils. Positive effects of teaching are achieved by a systematic review and evaluation of the effects of particular activities, corrections related to the selected teaching activities and methods, as well as to the pupils' workload. Positive effects of physical education classes may be obtained by determining characteristics of each individual pupil based on the teacher's observations. To achieve this, the physical education teacher has to be both an action researcher and a reflective practitioner in order to be able to critically evaluate not only their pupils' achievements but also the effects of their teaching. The question may be posed whether this approach to teaching is applied in physical education classes. This research is aimed at examining the physical education teachers' attitudes concerning the following issues: knowledge about action researches and their application in physical education teaching, preparation and planning of physical education classes, class management tactics, respecting order and discipline during physical education classes, evaluation and self-evaluation of teachers. A genuine contribution of this research to the field could be the possibility to evaluate the evaluation of physical education teachers.

\section{Instruments}

The instrument used in the research conducted with the physical education teachers in the context of reflective practice and action research is the Likert-type scale (FVAI). The instrument consists of 5 sub-scales, in accordance with the issues studied, with 40 items. The instrument showed an extremely high consistency of the variables. The reliability of 
the instrument was examined by Cronbach's Alpha test, which proved the consistency of the items construction and thus verified that the instrument fulfilled one of the most significant requirements of measuring instruments - reliability (Cronbach's Alpha $=0.91$ ).

\section{Variables and the sample}

The sample selection has the characteristics of a stratified sample. First, all primary and secondary school physical education teachers were listed. According to the official and available data, there are 1,337 primary state schools and 2,335 physical education teachers employed in them (http://osnovneskole.edukacija.rs/drzavne) and 517 secondary state schools with 939 physical education teachers in Serbia (http://srednjeskole.edukacija.rs/drzavnesrednje-skole/svi-gradovi). The sample was selected from every stratum (district) by random sampling both in direct contact and by online surveys. The sample consisted of 405 respondents with regard to their stage of education (primary and secondary) and years of teaching experience (0-10; 11-20; over 20 years of teaching experience). The obtained results contributed to a better understanding of physical education teachers as reflective practitioners and action researchers as regards the set independent variables.

\section{Statistical procedure}

The survey research method with a descriptive analysis was used. The Kaiser Mayer Olkin test showed that a factor analysis was justified $(\mathrm{KMO}=0.93$, desired value of the KMO test $=0.70$ ), while Bartlett's test value of $\mathrm{p}=0.00$ was statistically significant.

Five main components that explain approximately $55 \%$ of the total variance were determined by the component analysis. The results were further statistically processed using the parametric testing $\mathrm{t}$ and $\mathrm{F}$ (ANOVA) test and the Pearson correlation coefficient.

\section{RESULTS}

The main components were extracted from the Likert-type scale by means of a component analysis. The components were determined regarding the teachers' attitudes towards the set statements.

Table 1 Matrix of extracted components

\begin{tabular}{|c|c|c|c|c|c|c|c|c|c|}
\hline \multirow[t]{2}{*}{ Component } & \multicolumn{3}{|c|}{ Initial Eigenvalues } & \multicolumn{3}{|c|}{$\begin{array}{c}\text { Extraction Sums of Squared } \\
\text { Loadings }\end{array}$} & \multicolumn{3}{|c|}{$\begin{array}{c}\text { Rotation Sums of Squared } \\
\text { Loadings }\end{array}$} \\
\hline & Total & $\begin{array}{c}\% \text { of } \\
\text { Variance }\end{array}$ & $\begin{array}{c}\text { Cumulative } \\
\%\end{array}$ & Total & $\begin{array}{c}\% \text { of } \\
\text { Variance }\end{array}$ & $\begin{array}{c}\text { Cumulative } \\
\%\end{array}$ & Total & $\begin{array}{c}\% \text { of } \\
\text { Variance }\end{array}$ & $\begin{array}{c}\text { Cumulative } \\
\%\end{array}$ \\
\hline 1 & 11.245 & 37.482 & 37.482 & 11.245 & 37.482 & 37.482 & 4.335 & 14.451 & 14.451 \\
\hline 2 & 1.577 & 5.257 & 42.739 & 1.577 & 5.257 & 42.739 & 3.592 & 11.973 & 26.424 \\
\hline 3 & 1.361 & 4.536 & 47.275 & 1.361 & 4.536 & 47.275 & 3.493 & 11.643 & 38.067 \\
\hline 4 & 1.329 & 4.429 & 51.704 & 1.329 & 4.429 & 51.704 & 2.929 & 9.764 & 47.831 \\
\hline 5 & 1.147 & 3.822 & 55.526 & 1.147 & 3.822 & 55.526 & 2.012 & 6.705 & 54.536 \\
\hline
\end{tabular}

Extraction Method: Principal Component Analysis. 
Five main components were extracted and statistically analysed (54.54\% of the total variance). As regards the items set, the extracted components were the following:

1. Knowledge about action research and its application

2. Preparation and planning of physical education classes

3. Class management tactics

4. Order and discipline in physical education classes

5. Evaluation and self-evaluation of physical education teachers

First, it was tested whether physical education teachers were informed about action research and how much they knew about it.

The statistical analysis of the physical education teachers' answers provided the arithmetic mean $\mathrm{M}=3.00$ on the Likert-type scale (I neither agree nor disagree). After that, utilising the Anova F test, it was determined whether the difference in answers was statistically significant regarding the years of teaching experience (Table 2).

Table 2 Knowledge about action research in terms of years of teaching experience

\begin{tabular}{lcc}
\hline Teaching experience & Mean & $\begin{array}{c}\text { Std. } \\
\text { Deviation }\end{array}$ \\
\hline $0-5$ & 73.4189 & 8.18955 \\
$6-10$ & 73.1899 & 6.64498 \\
$11-20$ & 73.5067 & 7.65360 \\
Over 20 & 72.7143 & 6.11482 \\
Total & 73.2033 & 7.15096 \\
\hline \multicolumn{3}{c}{}
\end{tabular}

Statistically significant differences indicate that teachers had homogenous attitudes towards the knowledge and application of action research, i.e. that there was not a statistically significant difference in the respondents' answers regarding their years of teaching experience, $p>0.05$. A neutral attitude might mean that teachers had heard of action research but were not certain whether they applied it or not, and whether they applied all the components of action research during physical education classes.

Table 3 Knowledge about action research in terms of stage of education

\begin{tabular}{lcc}
\hline Stage of education (school) & Mean & Std. Deviation \\
\hline Primary & 72.5949 & 6.86729 \\
Secondary & 73.8571 & 7.41158 \\
\hline \multicolumn{3}{l}{$\mathrm{t}=1.54 ; \mathrm{df}=3 ; \mathrm{p}=0.12$}
\end{tabular}

Regarding the variable stage of education, i.e. the school at which they were employed, the teachers expressed similar attitudes. The statistical analysis determined that teachers had homogenous attitudes towards the knowledge and application of action research and there was no statistically significant difference in their answers irrespective of the stage of education at which they were employed (primary or secondary school), $p>0.05$. It cannot be definitely concluded whether action research is more present and more applied in either primary or secondary schools or whether years of teaching experience have an important 
impact on teachers being good action researchers. This means that the significance of action research can be promoted during physical education classes at both primary and secondary schools since teaching can be organised in innovative ways with purpose of realising all aspects of teaching. The results of the study show that the hypothesis was confirmed.

Table 4 Preparation and planning of physical education classes

\begin{tabular}{ccccc}
\hline & & $\begin{array}{c}\text { Preparation, } \\
\text { planning }\end{array}$ & $\begin{array}{c}\text { Stage of } \\
\text { education } \\
\text { (school) }\end{array}$ & $\begin{array}{c}\text { Years of } \\
\text { teaching } \\
\text { experience }\end{array}$ \\
\hline Preparation, planning & Pearson Correlation & 1 & $-.116(*)$ & $.342(* *)$ \\
& Sig. (2-tailed) & & .020 & .000 \\
& $\mathrm{~N}$ & 405 & 405 & 405 \\
\hline
\end{tabular}

* Correlation is significant at the 0.05 level (2-tailed).

** Correlation is significant at the 0.01 level (2-tailed).

Good preparation and planning should be done in cooperation with pupils and colleagues. Teachers have to be prepared for their classes, motivate their pupils, observe their reactions, interests and successful accomplishment of their learning tasks. The respondents in this research recognised the significance of this requirement since the component Preparation and planning of physical education classes was emphasised as statistically important. The research showed a statistically significant connection between preparation and planning of classes and independent variables of the research. Not only was the importance of the component Preparation and planning of physical education classes confirmed, but also of the first element of reflective teaching. The obtained result was a negative correlation, which means that preparation and planning of physical education classes were less practiced in secondary schools than in primary schools $(\mathrm{r}=-0,12), \mathrm{p}<0.05$. Teachers with longer teaching experience demonstrated a higher level of class preparation and planning $(\mathrm{r}=0.34), \mathrm{p}<0.05$. The results of the research confirms the assumption that planning and preparing physical education classes is linked to the education cycle and the years of teacher training $\mathrm{p}<0.05$.

Table 5 Class management tactics

\begin{tabular}{|c|c|c|c|c|}
\hline & & $\begin{array}{c}\text { Class } \\
\text { management }\end{array}$ & $\begin{array}{c}\text { Stage of } \\
\text { education } \\
(\text { school) }\end{array}$ & $\begin{array}{c}\text { Years of } \\
\text { teaching } \\
\text { experience }\end{array}$ \\
\hline \multirow{3}{*}{ Class management } & Pearson Correlation & 1 & $.141(* *)$ & $.326(* *)$ \\
\hline & Sig. (2-tailed) & & .004 & .000 \\
\hline & $\mathrm{N}$ & 405 & 405 & 405 \\
\hline
\end{tabular}

** Correlation is significant at the 0.01 level (2-tailed).

One of the components studied was Class management tactics. Teachers fulfilled one more condition necessary for practicing reflective teaching. A statistically significant correlation was observed between class management tactics, on the one hand, and stage of education and years of teaching experience, on the other. The correlation is positively increasing, which means that the reflexivity of teachers increases due to a higher stage of education (at secondary schools it was $r=0.14)$ and longer teaching experience $(r=0.33)$, 
$\mathrm{p}<0.05$. On the basis of the obtained data we conclude that the hypothesis related to conducting and course of the teaching is confirmed. The correlation with independent variables, education cycle and years of work experience of the teachers is present at the level of statistical significance, $\mathrm{p}<0.05$.

Table 6 Discipline in physical education classes

\begin{tabular}{llccc}
\hline & $\begin{array}{c}\text { Stage of } \\
\text { education } \\
\text { (school) }\end{array}$ & $\begin{array}{c}\text { Years of } \\
\text { teaching } \\
\text { experience }\end{array}$ & Discipline \\
\hline \multirow{2}{*}{ Discipline } & Pearson Correlation & $.134(* *)$ & $.302(* *)$ & 1 \\
& Sig. (2-tailed) & .007 & .000 & \\
& $\mathrm{~N}$ & 405 & 405 & 405 \\
\hline & $* *$ Correlation is significant at the 0.01 level (2-tailed).
\end{tabular}

As reflective practitioners, physical education teachers reflect on how to establish discipline in their classes, how to react to unwanted behaviour during physical education classes, how to adopt the perception of their pupils in order to act adequately and appropriately in every situation. The component Discipline in physical education classes was studied in the research. The correlation is positively increasing and this component is correlated with both stage of education (school) and years of teaching experience. The obtained results show that reflection on class discipline is more dominant among secondary school physical education teachers $(\mathrm{r}=0.13)$ and among teachers with longer teaching experience $(\mathrm{r}=0.30), \mathrm{p}<0.05$.

The assumption that the discipline is linked at the level of statistical significance with the independent variables of the research, the education cycle and the years of teacher's service has been confirmed.

Table 7 Grading and self-evaluation of physical education teachers

\begin{tabular}{|c|c|c|c|c|}
\hline & & $\begin{array}{l}\text { Evaluation and } \\
\text { self-evaluation }\end{array}$ & $\begin{array}{c}\text { Stage of } \\
\text { education } \\
\text { (school) }\end{array}$ & $\begin{array}{c}\text { Years of } \\
\text { teaching } \\
\text { experience }\end{array}$ \\
\hline \multirow{3}{*}{$\begin{array}{l}\text { Evaluation and } \\
\text { self-evaluation }\end{array}$} & Pearson Correlation & 1 & -.084 & $.291(* *)$ \\
\hline & Sig. (2-tailed) & & .090 & .000 \\
\hline & $\mathrm{N}$ & 405 & 405 & 405 \\
\hline
\end{tabular}

As regards grading and evaluation, teaching physical education presupposes assessment and evaluation of two aspects, i.e. two factors crucial for the system of education. Physical education teachers evaluate and identify the problems their pupils encounter during classes of physical education and receive some feedback on the quality of their teaching since good teaching is based on the continuous analysis and observation of pupils' accomplishments. However, teachers themselves should evaluate their own work continuously. Therefore, another important component studied was Evaluation and self-evaluation. The obtained results show that there is no significant correlation between this component of evaluation and stage of education (school), $\mathrm{p}<0.05$. On the other hand, the research proved that evaluation and selfevaluation were more evident in teachers with longer teaching experience $(r=0.29), p<0.05$. 
The data presented in Table 7 shows that the hypothesis about the connection of selfevaluation and teacher assessment with the education cycle and the length of the teachers' service is partially confirmed. Methods of evaluation and self-evaluation are not related to the education cycle $p>0.05$ but are related to years of service, $p<0.05$. This result leaves enough space to examine the ways of assessment and self-assessment in the work of teachers and pupils in elementary and secondary schools.

\section{DISCUSSION}

Physical education is a school subject which differs from other school subjects owing to its peculiarities. Its primary goals are the improvement of health, physical development, development of skills, formation and enhancement of motor skills, etc. For all these skills to be attained, specific and intrinsic activities are used - physical exercises (Rodić, 2010). The goals of physical education are accomplished during regular physical education classes and certain extracurricular activities (Batez et al., 2013). Another peculiarity of physical education classes is that they are not taught in a classroom, which raises the issue of whether the physical education teacher is a reflective practitioner and whether they can conduct action research. Yet, Ryan (2007) deliberates that managing a class of pupils, be it a school gym, scientific laboratory or a traditional classroom, requires a reflective leader, reflective skills and means (action research) in order to perfect practice. Knowledge about reflective practice in sports is beneficial to physical education teachers in their attempt at becoming reflective practitioners, i.e. action researchers in their field.

A large number of authors (Ahlberg et al., 2008; Cropley et al., 2010; Cropley et al., 2012; Hall \& Gray, 2016; Isidori, 2008; Kuklick et al., 2015; Pill, 2014; Robinson, 2013) have explored reflexive practice and action research in the field of sports. In one study on reflective practice (Knowles et al., 2006), "coaches" with a degree, i.e. physical education teachers emphasised that reflective practice meant: "Reassessment of what we have done and what we are doing at present, and, generally speaking, it is a process of evaluation (...) on the basis of which we perceive what segment of our practice we can best improve"; "Evaluation and observation of a series of events or one single event and discussion of what has happened (...), finding sense and making conclusions”; “(..) you sit and think about what you have done. I haven't made any success, so what can I do differently?"; “(...) You analyse your work and wonder what you can change in order to make it better". Therefore, teachers describe their reflective practice as a form of analysis, a process of evaluation, a means for improving their practice and introducing changes into it. The key factor is that teachers ask themselves two questions: "What have I done?" and "What can I do to make it better?"

Action research is conducted by teachers who put their knowledge into practice with the purpose of improving both their practical work and themselves as practitioners (Townsend, 2014), so it may be said that conducting action researches is closely linked to the reassessment of their own practice, which enables teachers to shape and share their rich teaching experience, but also to use it more systematically (Budjevac et al., 2013). Physical education differs from other forms of education by its particular characteristics. It is primarily aimed at health enhancement, development of physical skills, formation and 
improvement of motor skills, etc. All this is accomplished by means of particular activities - physical exercise.

The research on physical education teachers' attitudes proves that reflective practice is very important in practice and that reflection represents an integral part of teaching. Namely, reflective practice is singled out as the skill crucial for physical education teaching advancement, as a strategy that can help practitioners reassess their decisions and actions, which thus increases comprehension and management of one's own self and one's own practice.

\section{CONCLUSION}

Research in the field has proven that teachers evaluate themselves as reflective practitioners. Physical education teaching appears to be a segment of education which is most suitable for conducting action research. The obtained results further encourage physical education teachers to improve their knowledge in the field of action research, to teach applying innovative methods and to direct the aspects of reflection towards the evaluation of action research during physical education classes. Action research contributes to the creation of ideas that stimulate changes of teachers' perception of their own practice and opens up new possibilities for action that may be beneficial not only to teachers but also to their pupils since the conducted action research provides them with new information. Just like all teachers, physical education teachers are required to become reflective practitioners and to actively examine their own practice because it will be useful not only to them as teachers who have to continuously improve their teaching, but also to their pupils and colleagues.

This research proved that physical education teachers could start action research and progressively improve one of the most important segments of education - physical education of pupils, realised through the adequate physical development of children by means of action and reflection. This research also creates a possibility for some further training of physical education teachers in the field of action research. Namely, the teachers who were able to critically evaluate themselves and their own teaching are actually on the verge of realising action research and becoming true reflective practitioners. Therefore, they should be offered a possibility to learn the stages of conducting action research and to reflectively evaluate and record all the progress they have made in teaching and consequently compare their old methods of teaching with this innovative approach. Physical education teaching is particularly suitable for the realisation of action and attaining reflection on and evaluation of learning accomplishments.

\section{REFERENCES}

Ahlberg, M., Mallet, C.J., \& Tinning, R. (2008). Developing autonomy supportive coaching behaviors: An action research approach to coach development. International Journal of Coaching Science, 2(2), 1-20. Retrieved June 26, 2018 from the World Wide Web: http://selfdeterminationtheory.org/SDT/documents/ 2008_AhlbergMallettTinning_IJCS.pdf

Akbari, R., Kiany G.R., Imani Naeeni, M., \& Karimi Allvar, N. (2008). Teachers' teaching styles, sense of efficacy and reflectivity as correlates of students' achievement outcomes. IJAL, 11 (1), 1-28.

Altrichter, H., Posh, P., \& Somekh, B. (2005). Teachers investigate their work: An introduction to the methods of action research. London: Routledge. 
Anderson, A., Knowles, Z., \& Gilbourne, D. (2004). Reflective practice for applied sport psychologists: a review of concepts, models, practical implications and thoughts on dissemination. Sport Psychologist, 18, 188-201.

Apasia, D., Chrysoula, N., Panagiotis, S., \& Georgios, L. (2017). Physical education teachers' action research on teaching games for understanding. Mediterranean Journal of Social Sciences, 8 (2), 105-111.

Batez, M., Krsmanović, B., \& Dimitrić, G. (2014). The relationship between motor efficiency and teachers' competence. Teme, 38 (2), 917-928. In Serbian

Boateng, J. K., \& Boadi, C. (2015). Evaluating teachers of adult learners in reflective practice. International Journal of Economics, Commerce and Management, 3 (3), 1-15. Retrieved June 26, 2018 from the World Wide Web: http://ijecm.co.uk/wp-content/uploads/2015/03/3342.pdf

Buđevac, N., Jošić, S., Radišić, J., \& Baucal, A. (2013). Nastavnik kao refleksivni praktičar (The teacher as a reflex practitioner). Belgrade: The Ministry of Education, Science and Technological Development of the Republic of Serbia. In Serbian

Cropley, B., Hanton, S., Miles, A., \& Niven, A. (2010). Exploring the relationship between effective and reflective practice in applied sport psychology. The Sport Psychologist, 24 (4), 521-541.

Cropley, B., Hanton, S., Miles, A., \& Niven, A. (2012). The value of reflective practice in professional development: An applied sport psychology review. Sport Science Review, 19 (3-4), 179-208.

Evans, J., \& Light, R. (2007). Coach Development Through Collaborative Action Research: A Coach's Implementation of Game Sense Pedagogy. Asian Journal of Sports Science, 4 (1), 1-7.

Fatemipour, H. (2013). The efficiency of the tools used for reflective teaching in ESL contexts. ProcediaSocial and Behavioral Sciences, (93), 1398-1403.

Gilbert, W. D., \& Trudel, P. (2001). Learning to coach through experience: reflection in model youth sport coaches. Journal of Teaching in Physical Education, 21, 16-34.

Grk, A. (2010). Pedagoške kompetencije trenera u organizaciji koja uči (Pedagogical competencies of the trainer in the learning organization). Retrieved June 26, 2018 from the World Wide Web: https://www.researchgate.net/publication/210216752_Pedagogical_competence_of_coaches_in_a_learning organization

Hall, E. T., \& Gray, S. (2016). Reflecting on Reflective Practice: A Coach's Action Research Narratives. Qualitative Research in Sport. Retrieved June 25, 2018 from the World Wide Web: https://www.researchgate.net/publication/298805594_Reflecting_on_reflective_practice_a_coach's_action research_narratives

Huntley, E., Cropley, B., Gilbourne, D., Sparkes, A., \& Knowles, Z. (2014). Reflecting back and forwards: An evaluation of peer-reviewed reflective practice research in sport. Reflective Practice, 1-14. Retrieved June 25, 2018 from the World Wide Web: https://www.researchgate.net/publication/267447882_Reflecting_ back_and_forwards_an_evaluation_of_peer-reviewed_reflective_practice_research_in_sport

Isidori, E. (2008). Becoming a reflective practitioner in physical activity and sport. A new challenge for sport pedagogy. Studia Universitatis Babeş-Bolyai: Educatio Artis Gymnasticae, 53 (2), 33-38.

Kayapinar, U. (2016). A study on reflection in in-service teacher development: Introducing reflective practitioner development model. Educational Sciences: Theory \& Practice, 16 (5), 1671-1691.

Knowles, Z., Gilbourne, D., Borrie, A., \& Nevill, A. (2001). Developing the reflective sports coach: A study exploring the processes of reflective practice within a higher education coaching programme. Reflective Practice, 2 (2), 185-207.

Knowles, Z., Borrie, A., \& Telfer, H. (2005). Towards the reflective sports coach: Issues of context, education and application. Ergonomics, 48 (11-14), 1711-1720.

Knowles, Z., Tyler, G., Gilbourne, D., \& Eubank, M. (2006). Reflecting on reflection: Exploring the practice of sports coaching graduates. Reflective Practice, 7(2), 163-179.

Kuklick, C.R., Gearity, B.T., \& Thompson, M. (2015). Reflective practice in a university-based coach education program. International Sport Coaching Journal, 2, 248-260.

Mallett, C. (2004). Reflective Practices in Teaching and Coaching. Using reflective journals to enhance performance. In J. Wright, L. Dacdonald, \& L. Burrows (Eds.), Critical Inquiry and Problem-Solving in Physical Education (pp. 147-158). London: Routledge.

McGonagill, G. (2002). The Coach as Reflective Practitioner: Notes From a journey without end. In J. G. Berger, \& C. Fitzgerald (Eds.), Executive Coaching: Practices and Perspectives (pp. 59-85). Palo Alto: Davies-Black Publishing.

Mills, G.E. (2003). Action research: A guide for the teacher researcher. New Yersey: Merrill Prentice Hall.

Momčilović, Z., \& Momčilović, V. (2016). Attitudes of the students of the Teacher-Training Faculty in Vranje towards physical education. Facta Universitatis Series Physical Education and Sport, 14 (3), 455-462. 
Norton, L. S. (2009). Action Research in Teaching and Learning: A Practical Guide to Conducting Pedagogical Research in Universities. London: Routledge.

Olis, S., \& Sproule, J. (2007). Constructivist Coaching and Expertise Development as Action Research. International Journal of Sports Science \& Coaching, 2 (1), 1-14.

Osnovne državne škole u Srbiji (Primary state school in Serbia), Retrieved May 20, 2018 from the World Wide Web: http://osnovneskole.edukacija.rs/drzavne

Peppa, A., Asonitou, K., \& Koutsouki, D. (2011). Vježbanje učenika sa dijabetosom: uloga nastavnika fizičkog vaspitanja u školama (exercise training in students with diabetes: the role of pe teacher at school). SportLogia, 7 (2), 171-178. In Serbian

Pill, S. (2014). Coach development through collaborative action research: An Australian football coach's implementation of a game sense approach. University of Sydney Papers in HMHCE - Special Games Sense Edition, 31-50. Retrieved June 25, 2018 from the World Wide Web: https://sydney.edu.au/ education_social_work/research/centres_and_networks/ADPN/HMHCEpapers/resources/HMHCE_GS_Ed_Article_03_2014.pdf

Radišić, J., Buđevac, N., Jošić, S., \& Baucal, A. (2015). Nastavnik kao refleksivni praktičar: primeri dobre prakse (Teacher as a reflex practitioner: Examples of good practice). Belgrade: The Ministry of Education, Science and Technological Development of the Republic of Serbia. In Serbian.

Robinson, D.B. (2013). Getting girls in the game: Action research in the Gymnasium. Canadian Journal of Action Research, 14 (3), 3-28.

Rodgers, C. (2002). Defining reflection: Another look at John Dewey and reflective thinking. Teachers College Record, 104 (4), 842-866.

Rodić, N. (2010). Savremeno fizičko vaspitanje u razrednoj nastavi (Contemporary physical education in classroom teaching). Norma, 15(1), 47-59. In Serbian

Ryan, T.G. (2007). The reflexive classroom manager: A required pre-service mode. Networks, 9 (1), 1-6.

Sanopao, J.P. (2016). The reflective teaching practices and teaching performance of public secondary English teachers. International Journal of Social Science and Humanities Research, 4 (1), 358-367.

Srednje državne škole u Srbije (Secondary state school in Serbia), Retrieved May 20, 2018 from the World Wide Web: http://srednjeskole.edukacija.rs/drzavne-srednje-skole/svi-gradovi

Townsend, A. (2014). Weaving the threads of practice and research. In F. Rauch, A. Schuster, T. Stern, M. Pribila, \& A. Townsend (Eds.). Promoting change through action research (pp. 7-22). Rotterdam: Sense Publishers.

\section{PROFESORI FIZIČKOG VASPITANJA KAO PRAKTIČARI I AKTIVNI ISTRAŽIVAČI U SVOM ZANIMANJU}

Časovi fizičkog vaspitanja su posebnog karaktera u poređenju sa časovima drugih predmeta, jer se ne održavaju u učionici. Međutim, to sigurno ne znači da nastavnici fizičkog vaspitanja ne bi trebali razmišljati o njihovom praktičnom radu ili analiziranju istog. Ovaj proces reflektivnog razmišljanja predstavlja poseban izazov i odgovornost za nastavnike fizičkog vaspitanja. Dakle, cilj ovog istraživanja je da se odredi način na koji se pristupa ovom problemu, tj. da li su nastavnici fizičkog vaspitanja dobri praktičari i istraživači. U radu je korišćen deskriptivni metod $i$ tehnika skaliranja, kao i skale Likert tipa (FVAI), dizajnirane za potrebe ovog istraživanja, koje su ispitale stavove nastavnika o fizičkom vaspitanju u kontekstu ogledne neastave i istraživanja. Istraživanje je sprovedeno na uzorku od 405 ispitanika u odnosu na nezavisne varijable tipa škole (osnovno i srednje obrazovanje) $i$ godina službe (0-10, 11-20, preko 20 godina radnog iskustva). Ovo istraživanje je pokazalo da su nastavnici delimično informisani o aktivnom istraživanju $i$ njegovoj primeni, dok visoko cene sve aspekte ogledne nastave. Ovo istraživanje doprinosi afirmaciji aktivnog istraživanja jer su odlgedi i aktivnost povezani u nastavi fizičkog vaspitanja putem kontinuirane, neprekidne linije koja dalje podstiče nastavnike da razmišljaju o sopstvenoj praksi. Nastavnici koji su ogledni praktičari su istovremeno aktivni istraživači. Ovo istraživanje je dokazalo postojanje statistički značajne veze između oglednih komponenti nastavnika fizičkog vaspitanja i faze obrazovanja (škole) $u$ kojoj oni predaju i godina iskustva u nastavi, $p<0.05$.

Ključne reči: aktivno istraživanje, ogledna praksa, fizičko vaspitanje, nastavu fizičkog vaspitanja 